Original Paper http://ajol.info/index.php/ijbcs http://indexmedicus.afro.who.int

\title{
Ethnobotanical survey and genetic conservation of underutilized leafy vegetables in lagos, Nigeria
}

\author{
Temitope Olabisi ONUMINYA*, Oredolapo Ezekiel SHODIYA and \\ Peace Busola EHINJU
}

Department of Botany, University of Lagos, Akoka, Lagos, Nigeria.

*Corresponding author; E-mail:topssy4u@yahoo.co.uk

\section{ACKNOWLEDGMENTS}

This research was funded by University of Lagos CRC Grant: CRC NO. 2014/09.

\begin{abstract}
Many of the leafy vegetables used for food in Nigeria are neglected and underutilized. To assess their diversity in Lagos State, an ethnobotanical survey and genetic conservation was carried out to preserve indigenous knowledge on their usage and conserve their DNA for future use. This involved collection of leafy vegetables from eight different markets in Lagos followed by semistructured questionnaire-guided interview and extraction of DNA samples. Three hundred respondents participated in the study comprising $81.67 \%$ female and $18.3 \%$ male. A total of 19 leafy vegetables belonging to 18 genera and 14 plant families were documented. About $52.6 \%$ of the documented leafy vegetables are restricted to southern Nigeria, while $47.4 \%$ are available and used nationwide. All the collected samples yielded high molecular weight DNA; these have been deposited at the University of Lagos DNA bank. The purity of the samples was also high with exception to that of Crassocephalum cerepidioides and Heinsia crinata. This work has contributed to the preservation of knowledge on leafy vegetables in Lagos and conservation of their DNA can be seen as a first step in the genetic conservation of the samples serving as a basis upon which other research can be based.
\end{abstract}

() 2018 International Formulae Group. All rights reserved.

Keywords: Biorepositories, Ethnobotany, Indigenous Knowledge, Leafy Vegetables, NUS.

\section{INTRODUCTION}

Vegetables are the fresh and edible portions of herbaceous plants, which can be eaten raw or cooked (Dhellot et al., 2006). They contain both essential and toxic elements over a wide range of concentrations (Okorondu et al., 2013) which can be successfully utilized to build up and repair the body as well as maintain alkaline reserve of the body (Okolo et al., 2015). They also act as buffering agents for acidic substances produced during the digestion process (Badau et al., 2013).

Leafy vegetables most often include short-lived herbaceous plants such as lettuce and spinach; leaves of woody plants such as 
Adansonia, Aralia, Moringa, Morus and Toona as well as fodder crops (e.g. Alfalfa). They constitute the main portion of the diets of rural and urban households across most of Africa hence their conservation is of concern to both national and international agricultural research centers in the region (Gockowski et al., 2003). In Nigeria, as in most other tropical countries of Africa where the daily diet is dominated by starchy staple foods, leafy vegetables are the cheapest and most readily available sources of important proteins, vitamins minerals and essential amino acids (Aja et al. 2010; Olaposi and Adunni, 2010; Saramma and Padmaja, 2013). They are typically low in calories and fat, and high in protein per calorie, dietary, fiber, vitamin $\mathrm{C}$, pro-vitamin A, carotenoids, foliate, manganese and vitamin $\mathrm{K}$ (Adjatin et al., 2013). They occur in a variety of colors and flavors from sweet to bitter, from peppery to earthy. Some are used in traditional medicine; for weight management, in reducing the risk of cancer and heart diseases and also to improve immune function (George et al., 2004; Chaturvedi et al., 2007; Janick, 2011).

\section{Several researchers including} Adebooye and Opabode (2004) as well as Adebooye and Ajayi (2008) have shown concern for the fast rate at which the genetic base of the World's food is being eroded due to scientific concentration on very few crop varieties. Amujoyegbe et al. (2007) observed that the genetic diversity of vegetable crops in Africa generally, and in Nigeria in particular, was for a long time naturally preserved by the traditional cropping system. However, in the recent times, there has been rapid deterioration of natural resources resulting in the loss of genetic diversity due to pressure on land, as a result of human activities for industrialization and urbanization (Shebu and Sewuese, 2014). Factors such as rapid changes in land use, modernization of agricultural practices, deforestation and adoption of new varieties processing have narrowed genetic base and this has contributed to the rapid disappearance of many land races of cultivated vegetables and their wild relatives (Amujoyegbe et al.,
2007). Despite the nutritional and medicinal values of these vegetables, they have been scientifically neglected in place of the exotic ones which may even be nutritionally inferior. Although they are greatly appreciated for their taste and nutritional quality, they are often the first item to drop from the household diet when the economy of the family improves. Diouf et al. (2007) identified traditional vegetables as being associated with poor rural lifestyles and low status, hence cultural changes and urbanizations have led to further neglect in response to the decline in production, consumption and diversity of indigenous vegetables. This research therefore aimed at carrying out an ethnobotanical survey of underutilized leafy vegetables in Lagos State with a view to preserving indigenous knowledge on their usage and conserve their DNA for future use.

\section{MATERIALS AND METHODS}

\section{Source of plant materials}

Leafy vegetable samples were collected from eight different markets in Lagos State namely: Epe, Ikorodu, Yaba, Bariga, Mushin, Surulere, Oyingbo and Okeodo markets. A portion of each sample was kept in zip locked bags containing silica gel for preservation until it is ready for extraction. Voucher specimens were also prepared and deposited at the Lagos Herbarium in the Department of Botany, University of Lagos for reference purpose.

\section{Ethnobotanical survey of vegetable samples}

The ethnobotanical survey was conducted with the full consent of all respondents with further verbal agreement and understanding that the research shall not be used for commercial purposes, but to serve as enlightenment on the diversity of leafy vegetables in Lagos State and their medicinal uses. The method used followed Otang et al. (2012) with minor modifications. A semistructured questionnaire guided interview of respondents was carried out at each collection point to document information on the plant uses, method of usage, habit, form, maturity, period of availability, extent of consumption, 
degree of consumption, nutritional value, and medicinal uses of the leafy vegetables.

\section{Genetic conservation of vegetable samples Extraction of DNA samples}

Extraction of DNA samples was achieved following modified CTAB protocol by Doyle and Doyle (1987) with minor modifications as follows: The mortals and pestles were autoclaved before use in order to sterilize them. About $20 \mathrm{ml}$ of CTAB buffer was poured in a labeled blue cap tubes, $0.8 \mathrm{~g}$ of polyvinylpyrrolidone was added and $40 \mu \mathrm{l}$ of beta-mercaptoethanol was added to the solution under a fume cupboard then the mixture was kept in the water bath at $65{ }^{\circ} \mathrm{C}$ in order to dissolve the PVP. Mortar and pestles were preheated in the water bath at $65{ }^{\circ} \mathrm{C}$ for some minutes and used to grind two leaves of the different sample with silica gel (in order to hasten the grinding) into powder and $0.10 \mathrm{~g}$ of the powder was transfered into newly labeled $1.5 \mathrm{ml}$ Eppendorf tubes. About $800 \mu \mathrm{l}$ of the pre-warmed $\left(65^{\circ} \mathrm{C}\right)$ solution $(\mathrm{CTAB}$ buffer, polyvinylpyrrolidone and betamercaptoethanol) in the blue cap tube was added into the tube containing the powder and the mixture was swirled in order to suspend the slurry. The slurry was incubated at $65{ }^{\circ} \mathrm{C}$ for one hour and it was mixed by inverting every $5 \mathrm{~min}$. The mixture was rocked on an orbital shaker at $150 \mathrm{rpm}$ (rate per minute) for $30 \mathrm{~min}$ and it was spun in a centrifuge at $12000 \mathrm{rpm}$ for $5 \mathrm{~min}$ and the aqueous (top) phase was transferred into a new labeled 1.5 $\mathrm{ml}$ Eppendorf tube using sterile micropipettes and pipettes tips. The volume of the aqueous top phase was estimated and noted and equal volume of Sevag was added to each sample and mixed well to obtain an emulsion, it was further inverted for one minute, it was rocked on an orbital shaker for $30 \mathrm{~min}$ and centrifuged at $12000 \mathrm{rpm}$ for $10 \mathrm{~min}$ and sterile micropipettes were used to transfer the upper aqueous phase into a clean new $1.5 \mathrm{ml}$ Eppendorf tube. This stage was repeated. The volume of the repeated aqueous phase was added with the 0.08 volume of cold $7.5 \mathrm{M}$ ammonium acetate and then multiplied by 0.54 to give the volume of cold isopropanol to be added to the mixture; it was mixed well and kept in the freezer for $24 \mathrm{~h}$ to precipitate the DNA. Solution was removed from freezer and spun in the centrifuge at $12000 \mathrm{rpm}$ for 20 $\min$. The liquid was poured off and $700 \mu \mathrm{l}$ of cold $70 \%$ ethanol was added and mixed, it was then left to stand for few minutes or until the pellet becomes free. It was centrifuged for $5 \mathrm{~min}$ at $12000 \mathrm{rpm}$. The liquid was poured off. The pellet was washed twice using $700 \mu \mathrm{l}$ of cold $70 \%$ ethanol, the ethanol was poured off and the tubes were drained upside down in order to ensure complete removal of excess ethanol from the pellets and dried. The samples were eluted in $100 \mu \mathrm{l}$ of TE buffer and it was kept in the fridge overnight.

\section{Gel Electrophoresis}

The method described by Adeyemi and Ogundipe (2012) was followed. This was achieved using $1 \%$ agarose gel which was prepared by mixing $1.5 \mathrm{~g}$ agarose with $150 \mathrm{ml}$ $1 \mathrm{X}$ TBE buffer. The mixture was dissolved in a microwave for 2 min and $4 \mu$ lof safe view was added and swirled. The gel was poured into a gel tray containing combs and allowed to stand for at least $30 \mathrm{~min}$ for the gel to solidify. The combs were removed after the gel has solidified and the tray was transferred into the electrophoresis tank flooded with $1 \mathrm{X}$ TBE buffer. About $3 \mu \mathrm{l}$ of loading dye and 5 $\mu 1$ of DNA sample were spotted on a parafilm paper. The mixture was loaded into wells on the gel and this was run for $45 \mathrm{~min}$ at 110 amps and $60 \mathrm{~V}$. The quality of the DNA was then photographed under ultraviolet light using UVIdoc System.

\section{Spectrophotometric analysis}

This was done to determine the purity and concentration of extracted DNA samples. It involves measuring $55 \mu 1$ of distilled water into a cuvette for blank checking, followed by the addition of $5 \mu \mathrm{l}$ of DNA sample and mixing thoroughly avoiding bubbles. Then the cuvette was placed in the Biophotometer to determine the concentration of the sample, the relative absorbance at different wavelength $(230 \mathrm{~nm}, 260 \mathrm{~nm}$ and $280 \mathrm{~nm})$ and the absorbance ratio were determined and recorded for each of the samples. 


\section{Data analysis}

Data were analysed using descriptive statistics (frequencies, percentages) to generate summaries and tables.

\section{RESULTS}

A total of nineteen leafy vegetable samples were collected and photographed (Plate 1). The most frequently encountered of the vegetable was Amaranthus hybridus while the most frequently encountered families were Amaranthaceae and Asteraceae being represented by three species each followed by Lamiaceae represented by two species (Table 1). All the collected vegetable samples are cultivated and majority have herbaceous habit (84.2\%) however only Amaranthus hybridus, Basella alba, Celosia argentea, Corchorus olitorius, Crassocephalum cerepidioides, Ocimum gratissimum, Talinum triangulare, Telfairia occidentalis and Vernonia amygdalina are indigenous to the study area. Questionnaires were administered at each collection point and a total of 300 respondents
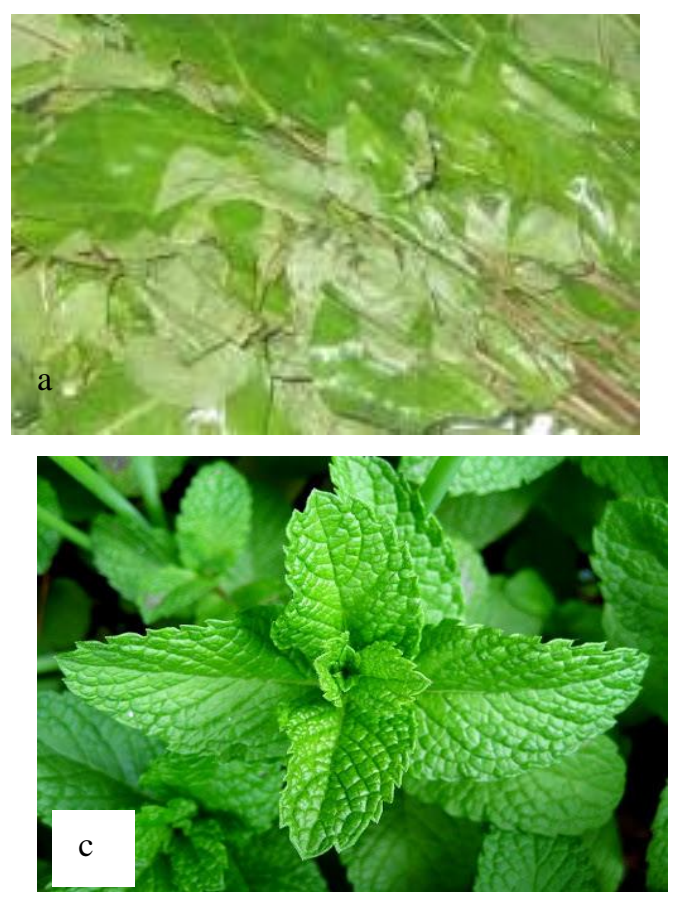

were questioned, of these, $81.67 \%$ are female while $18.3 \%$ are male. Also, $30 \%$ of the respondents were under 35 years old while $70 \%$ were between 35 and 65 years of age. About $52.6 \%$ of the documented leafy vegetables are restricted to Southern Nigeria while $47.4 \%$ are available and used throughout the country (Table 2). Major proportions of the vegetables collected are sold fresh while some sold dried. All the collected samples yielded good quantity and quality DNA samples; these have been deposited at the University of Lagos, DNA bank. The spectrophotometric analysis showed that Ocimum gratissimum, Talinum triangulare, Vernonia amygdalina and Gnetum africanum had the highest purity with absorbance ratio of 1.90 while Heinsia crinata had the lowest purity with absorbance ratio of 1.29. Corchorus olitorius had the highest concentration of $1335 \mathrm{ng} / \mu \mathrm{l}$ followed by Telfairia occidentalis with $1125 \mathrm{ng} / \mu \mathrm{l}$ and the least concentration $27 \mathrm{ng} / \mu \mathrm{l}$ was seen in Pterocarpus mildbreadii (Figures 1 and 2).

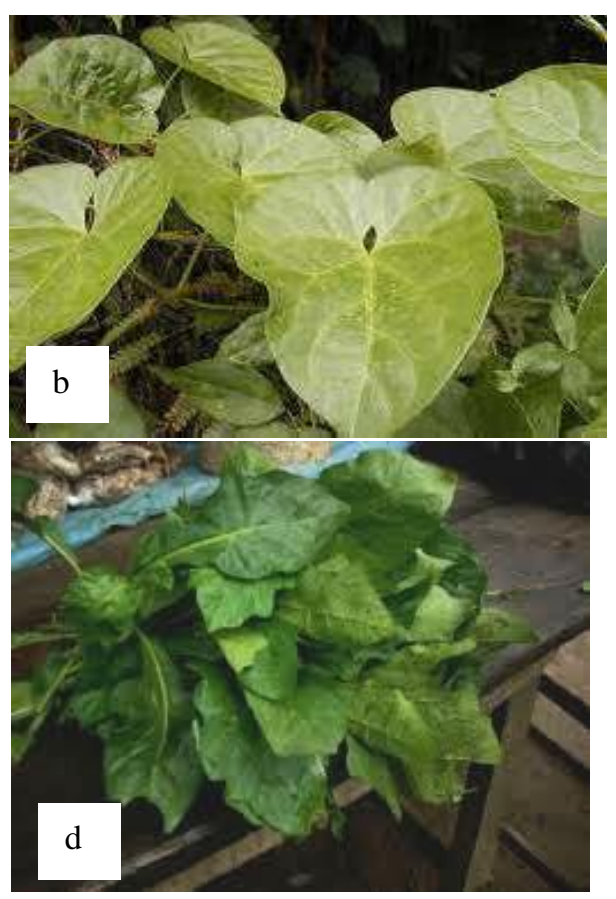


T. O. ONUMINYA et al. / Int. J. Biol. Chem. Sci. 12(2): 689-702, 2018
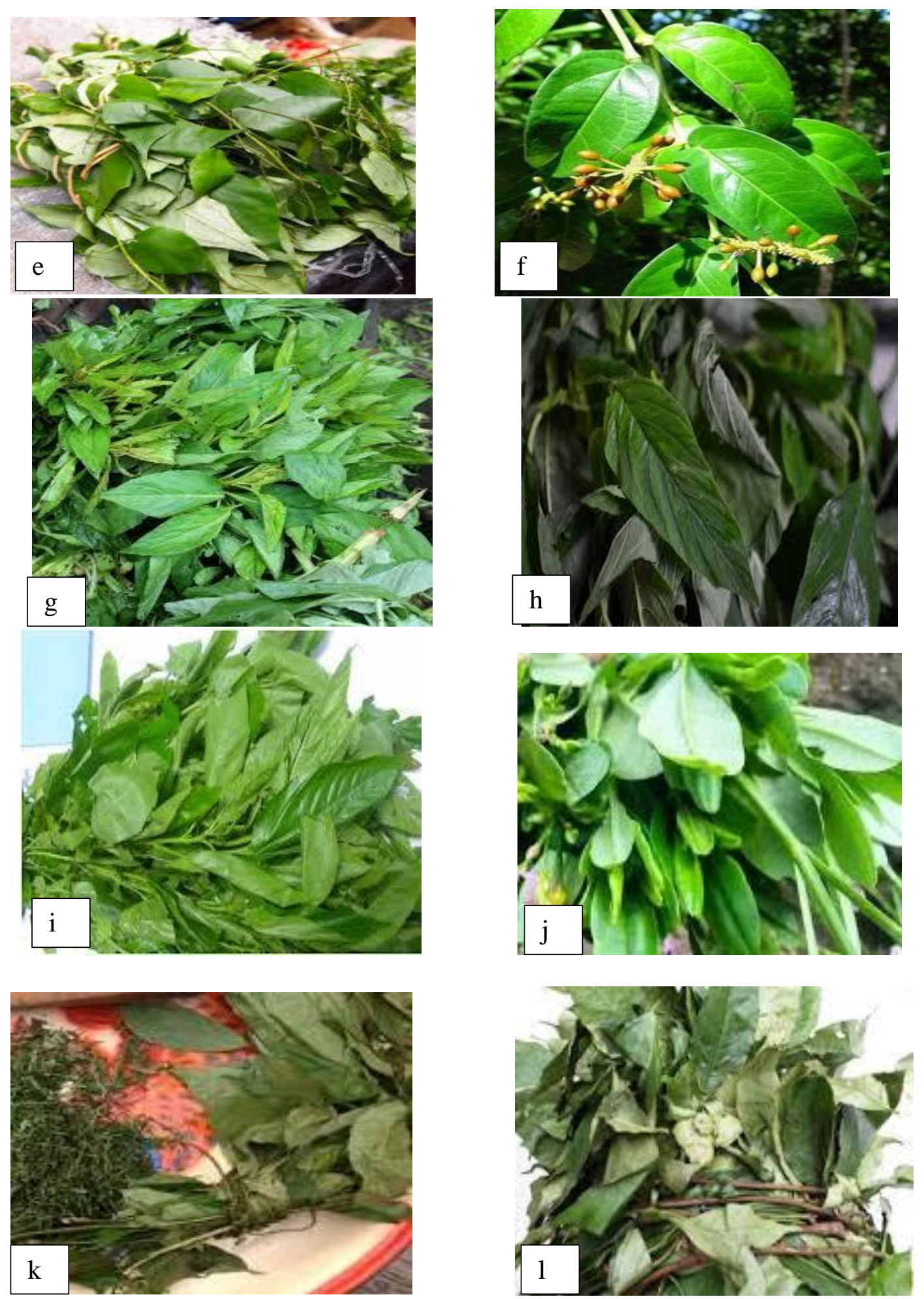

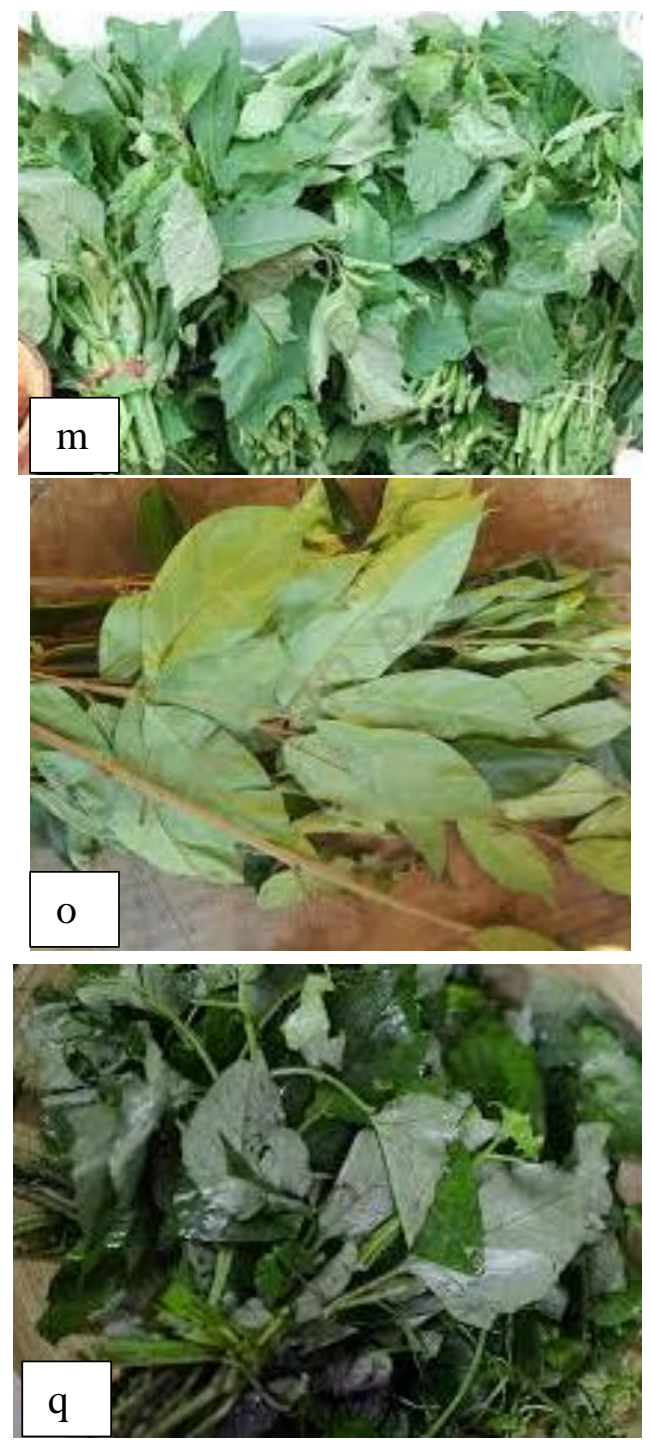
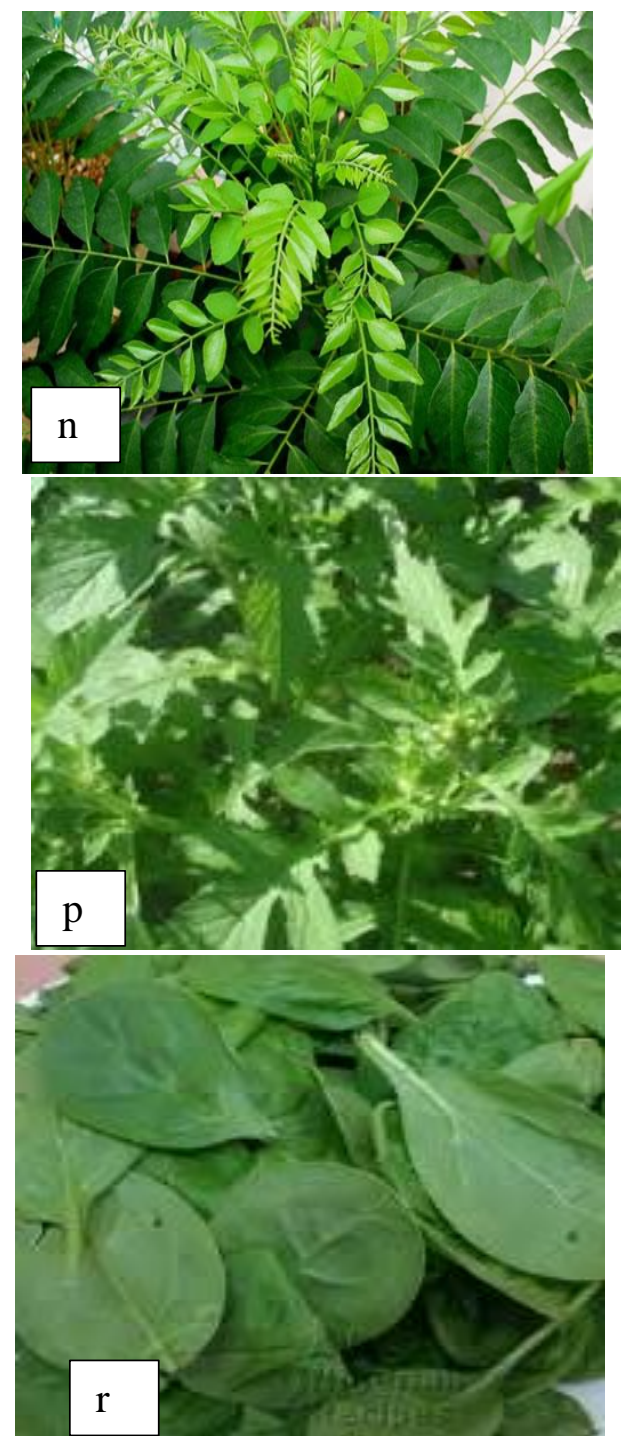

Plate 1: Leafy Vegetables in Lagos. (a) Pterocarpus mildbreadii, (b) Gongronema latifolium, (c) Ocimum gratissimum, (d) Solanum macrocarpon, (e) Telfairia occidentalis, (f) Piper guineense, (g) Celosia argentea, (h) Amaranthus hybridus, (i) Corchorus olitorius, (j) Talinum triangulare, (k) Lasianthera africana, (1) Gnetum africanum, (m) Vernonia amygdalina, (n) Murraya koenigii, (o) Heinsia crinite, (p) Crassocephalum cerepidioides, (q) Senecio biafrae, (r) Basella alba.

Table 1: List of leafy vegetables studied.

\begin{tabular}{|c|c|c|c|c|c|}
\hline S/N Botanical names & Family names & $\begin{array}{c}\text { Common } \\
\text { names }\end{array}$ & Local names & $\begin{array}{l}\text { Place of } \\
\text { collection }\end{array}$ & Coordinates \\
\hline \multirow[t]{2}{*}{$\begin{array}{l}\text { 1. Amaranthus } \\
\text { L. }\end{array}$} & Amaranthaceae & $\begin{array}{c}\text { Green } \\
\text { Amaranth }\end{array}$ & $\begin{array}{c}\text { 'Tete } \\
\text { abalaye' }\end{array}$ & Ikorodu & $\begin{array}{l}\text { N6 62.121, } \\
\text { E3 50.322 }\end{array}$ \\
\hline & & & & Surulere & $\begin{array}{l}\mathrm{N}^{\mathrm{N}} 06.51392^{\circ} \\
\mathrm{E}^{\circ} 03.34893^{0}\end{array}$ \\
\hline 2. Amaranthus viridis $\mathrm{L}$. & Amaranthaceae & $\begin{array}{c}\text { Slender } \\
\text { Amaranth }\end{array}$ & 'Soko' green & Epe & $\begin{array}{c}\text { N6 67.923, } \\
\text { E3 57.546 }\end{array}$ \\
\hline 3. Basella alba $\mathrm{L}$. & Basellaceae & Indian spinach & 'Amunututu' & Oke Odo & $\begin{array}{l}6^{\circ} 56^{\prime} 7.926 " \mathrm{~N} \\
3^{\circ} 13^{\prime} 26.31 " \mathrm{E}\end{array}$ \\
\hline
\end{tabular}


4. Celosia argentea L. Amaranthaceae Amaranth 'Soko' pupa $\quad$ Epe $\quad$ N6 67.923,

E3 57.546

Surulere $\quad \mathrm{N} 06.51392^{0}$

$\mathrm{E} 003.34893^{0}$

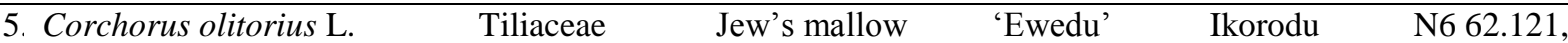

E3 50.322

Mushin N06.52731

E003.35275

6. Crassocephalum

Asteraceae

Fire weed

'Ebolo'

Oke Odo

$6^{\circ} 56^{\prime} 7.926^{\prime \prime} \mathrm{N}$

cerepidioides (Benth.)

$3^{\circ} 13^{\prime} 6.31 " \mathrm{E}$

S.Moore

7. Gnetum

Welw.

African

joint_fir

'Okasi' Oyingbo

N6 48.167,

E3 38.312

Oyingbo N06.48206

E003.38288 ${ }^{\circ}$

8. Gongronema latifolium Asclepiadaceae

Benth.

Amaranth

'Utasi'

N06.53748

9. Heinsia crinata (Afzel). globe E003.39221 ${ }^{\circ}$

G. Taylor

Rubiaceae

English bush

'Atama'

N06.48206 ${ }^{\circ}$

Lasianthera apple $\mathrm{E} 003.38288^{\circ}$

Lasianthera africana Stemonuraceae

'Editan’

$\mathrm{N} 06.48206^{0}$ Beauv

1 Murraya

koenigii
Spreng. L.

1. Piper guineense Piperaceae

Schumach.

1. Pterocarpus mildbreadii Harms.

Fabaceae

Curry leaf
$\mathrm{E} 003.38288^{\circ}$ N06.48206 $\mathrm{E} 003.38288^{\circ}$

$\begin{array}{llll}\text { Scent leaf } & \text { 'Efinrin’ } & \text { Bariga } & \text { N06.53748 }\end{array}$
$\mathrm{E} 003.39221^{0}$

\begin{tabular}{cccc}
$\begin{array}{c}\text { Ashanti } \\
\text { pepper }\end{array}$ & 'Uziza' & Bariga & $\begin{array}{r}\text { N06.53748 } \\
\text { E003.39221 }\end{array}$ \\
\hline African & 'oha' & Oyingbo & N6 48.167,
\end{tabular}

African 'oha' $\quad$ Oyingbo N6 48.167,
padauk

E3 38.312

Bariga N06.53748
E003.3922 $1^{0}$

1: Solanum macrocarpon Solanaceae Egg plant

'Igbo' N6 62.121, L.

Ikorodu

E3 50.322

Bariga

N06.53748 E003.3922 $1^{0}$

11 Senecio biafrae Oliv. \& $\quad$ Asteraceae $\quad$ Bologi $\quad$ 'Worowo' $\quad$ Oke Odo $\quad 6^{\circ} 56^{\prime} 7.926 " \mathrm{~N}$ Hiern.

1' Talinum triangulare Portulaceae (Jacq.) Willd.

Water leaf 年13'26.31"E

N6 67.923,

E3 57.546

Epe
E3 67.923,

Mushin N06.52731 ${ }^{\circ}$

E003.35275

1: Telfairia occidentalis $\quad$ Cucurbitaceae $\quad$ Fluted Hook. pumpkin

'Ugwu'

Oyingbo

N6 48.167

Bariga

E3 38.312

$\mathrm{N} 06.53748^{\circ}$

E003.39221 ${ }^{0}$

1! Vernonia amygdalina Asteraceae

Bitter leaf

'Ewuro'

Epe

N6 67.923,

Del.

Oyingbo

E3 57.546

N06.48206 ${ }^{0}$

E003.38288 
Table 2: Important leafy vegetables in Lagos State Nigeria.

\begin{tabular}{|c|c|c|c|c|c|c|c|}
\hline Samples & Habits & $\begin{array}{l}\text { Parts } \\
\text { Used }\end{array}$ & $\begin{array}{c}\text { Periods of } \\
\text { Availability }\end{array}$ & $\begin{array}{c}\text { Extent of } \\
\text { Consumption }\end{array}$ & $\begin{array}{c}\text { Degree of } \\
\text { Consumption }\end{array}$ & $\begin{array}{l}\text { Nutritional } \\
\text { Value }\end{array}$ & Medicinal Value \\
\hline Amaranthus viridis & Herbs & Whole & All year round & Country wide & High & $\begin{array}{l}\text { Vitamins and } \\
\text { minerals }\end{array}$ & Nutrient supplement \\
\hline $\begin{array}{l}\text { Amaranthus } \\
\text { hybridus }\end{array}$ & Herbs & Whole & All year round & Country wide & High & $\begin{array}{l}\text { Vitamins and } \\
\text { minerals }\end{array}$ & $\begin{array}{l}\text { Tapeworm expellant, relief } \\
\text { pulmonary problems }\end{array}$ \\
\hline Basella alba & Herbs & Leaf & All year round & $\begin{array}{c}\text { Restricted } \\
\text { (south-west) }\end{array}$ & Average & $\begin{array}{l}\text { Vitamins and } \\
\text { minerals }\end{array}$ & Laxative \\
\hline Celosia argentea & Herbs & Whole & All year round & Country wide & Average & $\begin{array}{l}\text { Vitamins and } \\
\text { minerals }\end{array}$ & Laxative, Cough \\
\hline Corchorus olitorious & Herbs & Leaf & All year round & $\begin{array}{c}\text { Restricted } \\
\text { (south-west) }\end{array}$ & Average & $\begin{array}{l}\text { Vitamins and } \\
\text { minerals }\end{array}$ & $\begin{array}{l}\text { Aids child delivery, bowel } \\
\text { movement }\end{array}$ \\
\hline $\begin{array}{l}\text { Crassocephalum } \\
\text { cerepidioides }\end{array}$ & Herbs & Leaf & All year round & $\begin{array}{c}\text { Restricted } \\
\text { (south-west) }\end{array}$ & Average & $\begin{array}{l}\text { Vitamins and } \\
\text { minerals }\end{array}$ & $\begin{array}{l}\text { Indigestion, stomach ache, } \\
\text { headache, to stop nose bleeding }\end{array}$ \\
\hline Gnetum africanum & Shrub & Leaf & All year round & $\begin{array}{l}\text { Restricted } \\
\text { ( south-east) }\end{array}$ & High & Spices & $\begin{array}{c}\text { Antiseptic, childbirth, sore throat } \\
\text { treatment }\end{array}$ \\
\hline $\begin{array}{l}\text { Gongronema } \\
\text { latifolium. }\end{array}$ & Herbs & Whole & All year round & $\begin{array}{l}\text { Restricted (south- } \\
\text { west) }\end{array}$ & Average & Spices & $\begin{array}{c}\text { Stomach ache, to aid walking in } \\
\text { infants }\end{array}$ \\
\hline Heinsia crinata & Herbs & Whole & All year round & $\begin{array}{c}\text { Restricted } \\
\text { ( south-east) }\end{array}$ & Average & $\begin{array}{l}\text { Vitamins and } \\
\text { minerals }\end{array}$ & $\begin{array}{l}\text { Pain relief, in arthritis and } \\
\text { rheumatism }\end{array}$ \\
\hline $\begin{array}{l}\text { Lasianthera } \\
\text { africana }\end{array}$ & Herbs & Whole & All year round & $\begin{array}{c}\text { Restricted } \\
\text { ( south-east) }\end{array}$ & Average & $\begin{array}{l}\text { Vitamins and } \\
\text { minerals }\end{array}$ & $\begin{array}{c}\text { As antacid, analgesic, anti- } \\
\text { ulcergenic, } \\
\text { anti-diabetic } \\
\text { and anti-malarial }\end{array}$ \\
\hline
\end{tabular}


T. O. ONUMINYA et al. / Int. J. Biol. Chem. Sci. 12(2): 689-702, 2018

\begin{tabular}{|c|c|c|c|c|c|c|c|}
\hline Murraya koenigii & Herbs & Whole & All year round & Country wide & Average & Spices & $\begin{array}{l}\text { For vomiting, dysentery and } \\
\text { diabetes. }\end{array}$ \\
\hline $\begin{array}{l}\text { Ocimum } \\
\text { gratissimum }\end{array}$ & Herbs & Leaf & All year round & $\begin{array}{c}\text { Restricted } \\
\text { (south-west) }\end{array}$ & Average & Spices & $\begin{array}{l}\text { Fever, diarrhea, dysentery, pile, } \\
\text { stomach problems, HBP }\end{array}$ \\
\hline Piper guineense & Tree & Leaf & All year round & Countrywide & High & Spices & Aphrodisiac \\
\hline $\begin{array}{l}\text { Pterocarpus } \\
\text { mildbreadii }\end{array}$ & Tree & Leaf & All year round & Countrywide & High & $\begin{array}{l}\text { Vitamins and } \\
\text { minerals }\end{array}$ & Skin infections \\
\hline $\begin{array}{l}\text { Solanum } \\
\text { macrocarpon }\end{array}$ & Herbs & Leaf & $\begin{array}{l}\text { Wet season } \\
\text { (April) }\end{array}$ & $\begin{array}{l}\text { Restricted } \\
\text { (south) }\end{array}$ & Low & $\begin{array}{l}\text { Vitamins and } \\
\text { minerals }\end{array}$ & $\begin{array}{l}\text { Treat ringworm, mouth ulcer, } \\
\text { reduce flatulence }\end{array}$ \\
\hline Senecio biafrae & Herbs & Leaf & $\begin{array}{l}\text { Wet season } \\
\text { (April) }\end{array}$ & $\begin{array}{l}\text { Restricted } \\
\text { (south) }\end{array}$ & Low & $\begin{array}{l}\text { Vitamins and } \\
\text { minerals }\end{array}$ & $\begin{array}{l}\text { Heart problem, cough, wound } \\
\text { dressing, rheumatism, tonic }\end{array}$ \\
\hline Talinum triangulare & Herbs & Whole & $\begin{array}{l}\text { Wet season } \\
\text { (April- Sept) }\end{array}$ & Country wide & High & $\begin{array}{l}\text { Vitamins and } \\
\text { minerals }\end{array}$ & $\begin{array}{c}\text { Potherbs, stomach problem. } \\
\text { nutrient supplements }\end{array}$ \\
\hline $\begin{array}{l}\text { Telfairia } \\
\text { occidentalis }\end{array}$ & Herbs & Whole & All year round & Country wide & High & $\begin{array}{l}\text { Vitamins and } \\
\text { minerals }\end{array}$ & $\begin{array}{c}\text { Blood tonic and nutrient } \\
\text { supplement }\end{array}$ \\
\hline $\begin{array}{l}\text { Vernonia } \\
\text { amygdalina }\end{array}$ & Shrub & Whole & All year round & Country wide & High & $\begin{array}{l}\text { Vitamins and } \\
\text { minerals }\end{array}$ & $\begin{array}{c}\text { Antimicrobial, antiseptic, } \\
\text { antimalaria }\end{array}$ \\
\hline
\end{tabular}




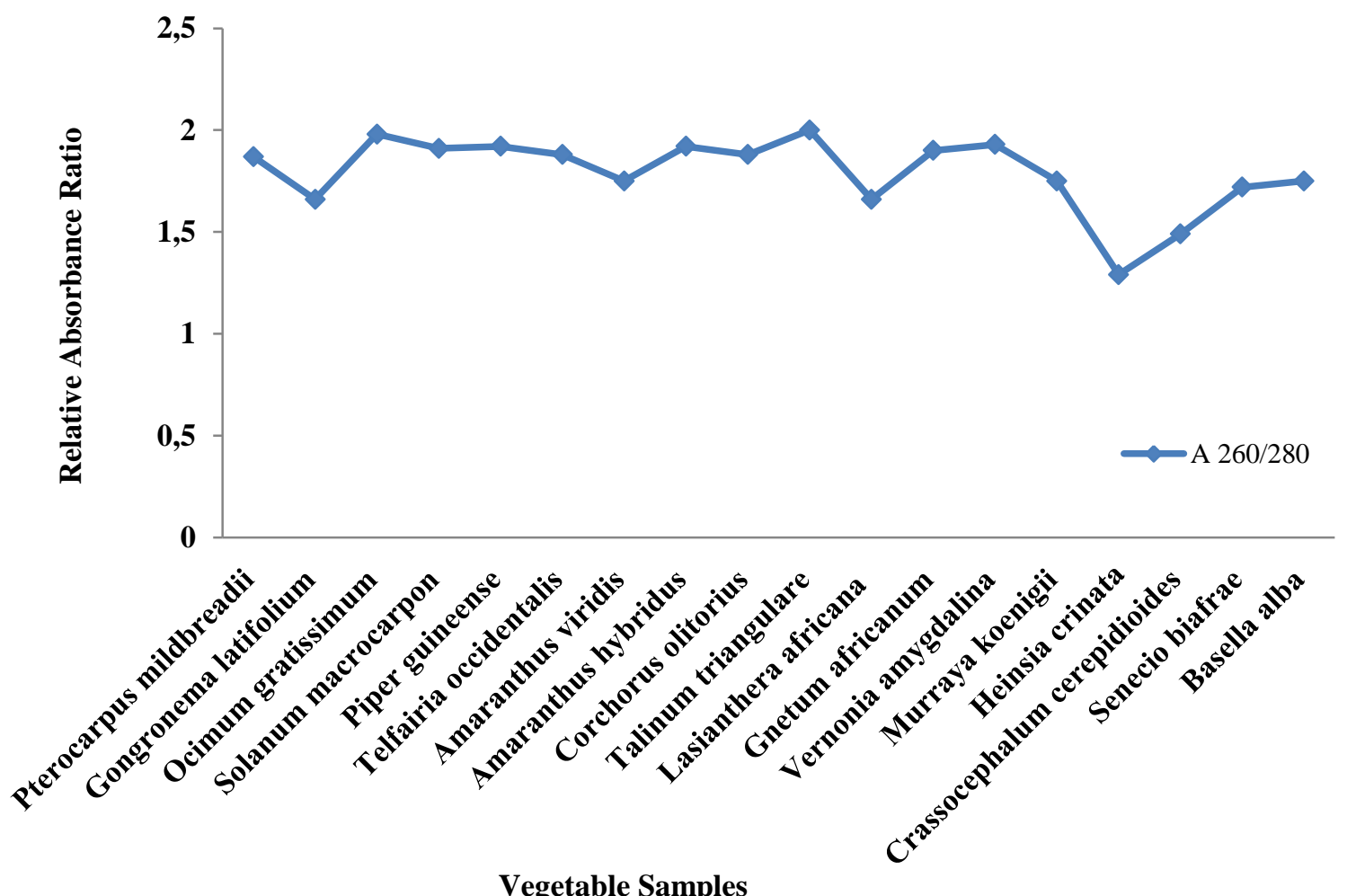

Figure 1: Absorbance ratio of samples.

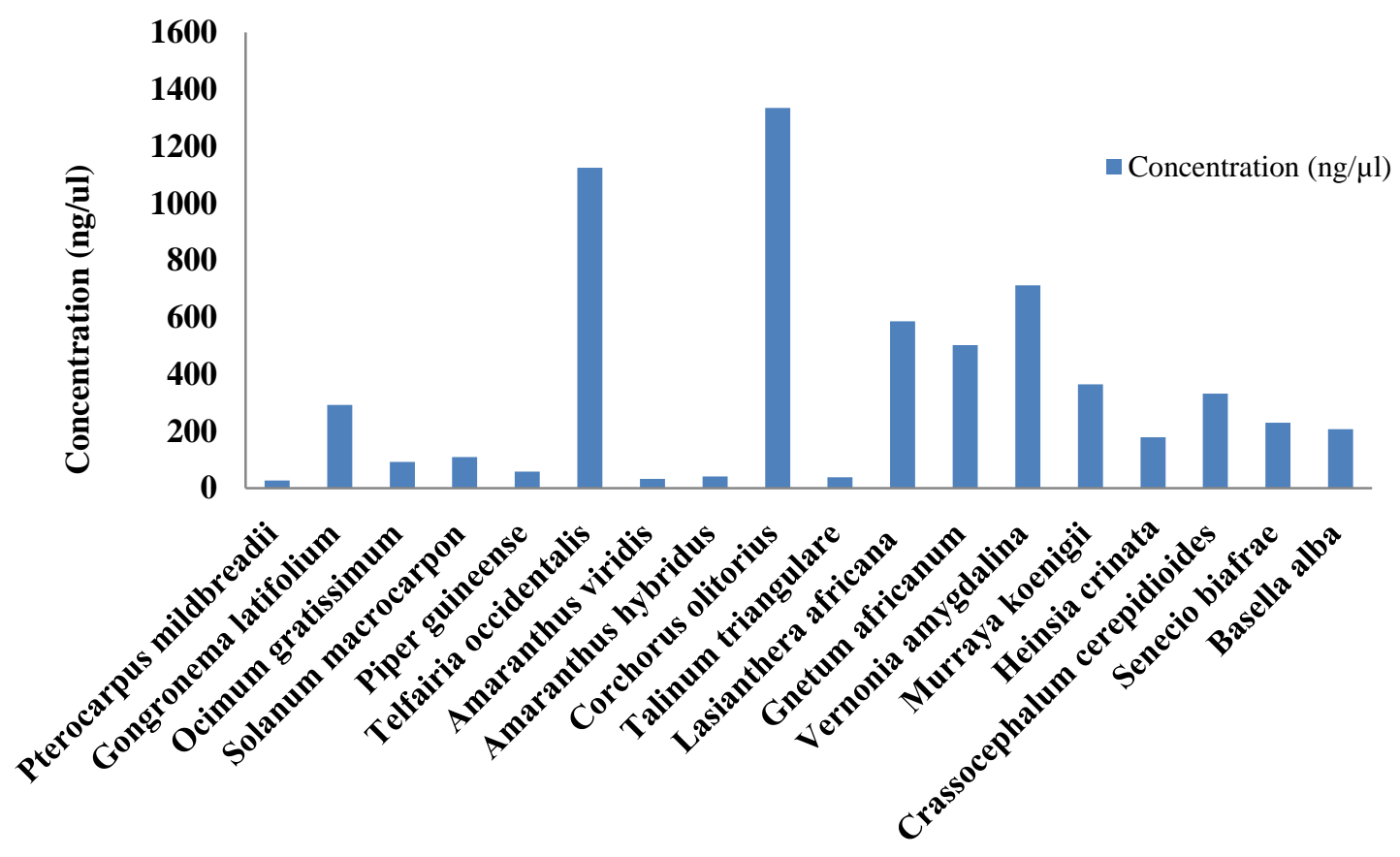

Vegetable Samples

Figure 2: Concentration of DNA samples. 


\section{DISCUSSION}

The result of this investigation showed that a number of vegetables retrieved from the Lagos markets are underutilized and indigenous knowledge regarding the use of these species is not uniformly distributed among the people. A high number of female respondents were recorded, this may be attributed to the fact that women are more involved in the marketing of leafy vegetables and they are generally responsible for the upkeep of the home and families (Gockowski et al., 2003; Zobolo and Mkabela, 2006). This observation is consistent with that of Ahmad and Jayed (2007), who opined that women folk provide the most valuable source of indigenous knowledge of plants. Also, the young age of the respondents shows that knowledge on the use of leafy vegetables is not yet endangered in the study area.

Owing to their weedy nature, these vegetables are mostly available all year round with exception to Talinum triangulare, Solanum macrocarpon and Scenecio biafrae which are available during the wet season. This is in line with the report of Adjatin et al. (2013), who reported that indigenous leafy vegetables are available all year round because they can be collected at the time of plenty, sun dried, stored and further used, when needed, during the long dry season. About $52.6 \%$ of the documented leafy vegetables are restricted to southern Nigeria while $47.4 \%$ are available and used throughout the country being widely known for their vitamin and mineral composition. Even so, only a fraction of the other $40 \%$ is known to the urban population and contributes to its diet. This is in contrast to Gockowski et al. (2003) who suggested that urban population are still first generation rural migrants who retain their preferences for these traditional foods and provide a base for efforts to promote the commercialization and use of these crops.
Furthermore, indigenous leafy vegetables have long been known and reported to have health protecting properties and uses (Okeno et al., 2003) and are being continually used for prophylactic and therapeutic purposes by rural communities (Smith and Eyzaguirre, 2007). This is further corroborated by the result of this study which shows a great diversity of leafy vegetables found in Lagos is of therapeutic value. It also indicates the potentials of these plants in enhancing both the nutrition and health care of average Lagosians in the face of harsh economic crisis as reported by Schippers (2000).

Also, underutilized vegetables are poorly represented in ex-situ gene bank collections hence special effort is required to collect genetic diversity (Padulosi et al., 2014). All the collected samples yielded good quantity and quality DNA samples; however there was a variation in the movement of DNA samples in gel; this is an indication that the DNA samples are of different molecular weight; the lower the molecular weight of the DNA, the faster the migration of gel and vice versa (Adeyemi and Ogundipe, 2012). Also, low spectrophotometric values were obtained in some of the samples and this could be as a result of contaminants present in the DNA which may also affect the visibility of the bands. Concentration of the samples also varied. The DNA extraction protocol used has proven to be advantageous due to its simplicity and quickness resulting in a high molecular weight DNA of good quality from the vegetables. According to Ayodele, the establishment of a gene bank for these vegetables will safeguard the future availability of their genetic resources which could be supplied for cultivation in gardens for subsistence and cash generation. Also, Lachkovics (2001) stated that the utilization of traditional vegetables enhances food security and the conservation of their genetic resources may contribute to new ideas and 
products of value to society in the future. Again, ex-situ conservation of agricultural biodiversity is highly strategic to society, but its role is also effectively static in nature and needs to be integrated with in situ/on-farm conservation efforts for maximum effectiveness (Barbieri et al., 2014).

\section{Conclusion}

This study is in line with the on-going efforts of previous authors towards documentation of indigenous knowledge of leafy vegetables in Nigeria. The ethnobotanical survey has contributed to the preservation of knowledge on leafy vegetables in Lagos and conservation of their DNA can be seen as a first step in the genetic conservation of the samples serving as a basis upon which other research can be based.

\section{COMPETING INTERESTS}

The authors declare that they have no competing interests.

\section{AUTHORS' CONTRIBUTIONS}

TOO: Development of the concept and experiment design, sample collection and identification, compilation of manuscript. OES: Sample collection, Ethnobotanical survey of collected samples. PBE: Sample collection, preparation of reagents, extraction of samples and analysis.

\section{ACKNOWLEDGEMENTS}

The authors are grateful to the Head, Molecular Systematics Laboratory for providing the lab space for this research.

\section{REFERENCES}

Adebooye OC, Ajayi OA. 2008. Future of the Nigerian under-exploited indigenous fruits and vegetables in the era of climate change: The Need for farmers Education. Conference on International Research on Food Security, Natural Resource Management and Rural Development,
Tropentag 2008. University of Hohenheim.

Adebooye OC, Opabode JT. 2004. Status of conservation of the indigenous leaf vegetables and fruits of Africa. African Journal of Biotechnology, 3(12): 700-705

Adeyemi TO, Ogundipe OT. 2012. Preliminary Studies on Isolation of Genomic DNA suitable for PCR from some African Sapindaceae. Biotechnology, 11(3): 172-177. DOI: 10.3923/biotech.2012.172.177

Adjatin A, Dansi A, Badoussi E, Sanoussi AF, Dansi M, Azokpota P, Ahissou $\mathrm{H}$, Akouegninou A, Akpagana K, Sanni A. 2013. Proximate, mineral and vitamin $C$ composition of vegetable Gbolo [Crassocephalum rubens (Juss. ex Jacq.) S. Moore and $C$. crepidioides (Benth.) S. Moore] in Benin. Int. J. Biol. Chem. Sci., 7(1): 319-333. DOI: http://dx.doi.org/10.4314/ijbcs.v7i1i.27

Ahmad SS, Javed S. 2007. Exploring the Economic Value of Underutilized Plant Species in Ayubia National Park. Pak. J. Bot., 39(5): 1435-1442.

Aja PM, Okaka ANC, Onu PN, Ibiam U, Urako AJ. 2010. Phytochemical composition of Talinum triangulare (Water Leaf) Leaves. Pakistan Journal of Nutrition, 9(6): 527-530. DOI: 10.3923/pjn.2010.527.530

Amujoyegbe BJ, Obisesan IO, Ajayi AO, Aderanti FA. 2007. Disappearance of Kersting's groundnut (Macrotyloma geocarpum) (Harms) Marechal and Baudet) in southwestern Nigeria: and indicator of genetic erosion. Plant Genetic Resources Newsletter, 152: 45-50.

Ayodele AE. The medicinally important leafy vegetables of South western Nigeria. http:/www.sju.edu/-

ebl/leaflets/ayodele.htm Registration in the data bank prelude: Reference: HA 32.

Badau MH, Abba HZ, Agbara GI, Yusuf AA. 2013. Proximate composition, mineral 
content and acceptability of granulated maize dumpling (Dambu Masara) with varying proportions of ingredients. Global Advanced Research Journal of Agricultural Science, 2(1): 007-016. http://garj.org/garjas/index.htm.

Barbieri RL, Gomes JC, Alercia A, Padulosi S. 2014. Agricultural Biodiversity in Southern Brazil: Integrating Efforts for Conservation and Use of Neglected and Underutilized Species. Sustainability, 6: 741-757. DOI: $10.3390 / \mathrm{su} 6020741$

Chaturvedi P, George S, John A. 2007. Preventive and protective effects of wild Basil in ethanol -induced liver toxicity in rats. Br. J. Biomed. Sci., 64(1): 10-12. DOI: https://doi.org/10.1080/09674845. 2007.11732748

Dhellot JR, Matouba E, Maloumbi MG, Nzikou JM, Safou-Ngoma DG, Linder M, Desobry S, Parmentier M. 2006. Extraction, chemical composition and nutritional characterization of vegetable oils: Case of Amaranthus hybridus (Var 1 and 2) of Congo Brazzaville. African Journal of Biotechnology, 5(11): 10951101. DOI: https://doi.org/10.5897/ AJB05.369

Diouf M, Lo C, Gueye M, Mbengue NB. 2007. Sélection participative de nouveaux cultivars de quatre (4) espèces de légumesfeuilles (Hibiscus sabdariffa L., Amaranthus L. spp, Vigna unguiculata (L.) WALP et Moringa oleifera Lam) au Sénégal. Afri. J. Food Agric. Nutr. Dev., 7(3): 17.

Doyle JJ, Doyle JL. 1987. A rapid DNA isolation procedure for small quantities of fresh leaf tissue. Phytochemical Bulletin, 19: $11-15$.

George S, Chaturvedi P, Reseroka BH, Mpho M, Makate, N. 2004. Hypoglycemic effect of methanol extract of Ocimum suave on albino rats. J. Appl. Zoo. Res., 15(2): 189194.
Gockowski J, Mbazo'o J, Mbah G, Moulende TF. (2003). African traditional leafy vegetables and the urban and peri-urban poor. Food Policy, 28: 221-235. DOI: 10.1016/S0306-9192(03)00029-0

Janick J. (Editor) 2011. Horticultural Review. (vol. 38) Wiley Blackwell: USA. 305.

Lachkovics E. 2001. Biologische VielfaltWer kontrolliert die globalen genetischen Ressourcen? Von der Lebensnotwendigkeit und der Ausbeutung der biologischen Vielfalt. In Biologische Vielfalt. Wer kontrolliert die globalen genetischen Ressourcen? Klaffenbo "ck G, Lachkovics E, Su"dwind Agentur (eds). Brandes \& Apsel Verlag: Frankfurt. 9-18

Okeno JA, Chebet DK, Mathenge PW. 2003. Status of indigenous vegetables in Kenya. Acta Hort., 621: 95-100.

Okolo I, Owolabi OA, James DB, Sallau AB, Andongma BT, Moses CA. 2015. The haemoglobin regeneration potential of fermented and unfermented Telfaira occidentalis and Gnetum africanum leaves in iron deficient albino rats. Int. J. Biol. Chem. Sci., 9(4): 1742-175 DOI: http://dx.doi.org/10.4314/ijbcs.v9i4.1

Okorondu SI, Akujobi CO, Okorondu JN, Anyado-Nwadike SO. 2013. Antimicrobial activity of the leaf extracts of Moringa oleifera and Jatropha curcas on pathogenic bacteria. Int. J. Biol. Chem. Sci., 7(1): 195-202. DOI: http://dx.doi.org/10.4314/ijbcs.v7i1i.16

Olaposi AR, Adunni AO. 2010. Chemical composition of three traditional vegetables in Nigeria. Pakistan Journal of Nutrition, 9(9): $\quad 858-860 . \quad$ DOI: 10.3923/pjn.2010.858.860

Otang WM, Grierson DS, Ndip RD. 2012. Ethnobotanical survey of medicinal plants used in the management of opportunistic fungal infections in the HIV/AIDS in the Amathole District of the Eastern Cape Province, South Africa. Journal of Medicinal Plant Research, 6(11): 2071- 
2080. DOI: https://doi.org/10.5897/ JMPR11.069

Padulosi S, Amaya K, Jäger M, Gotor E, Rojas W, Valdivi R. 2014. A Holistic Approach to Enhance the Use of Neglected and Underutilized Species: The Case of Andean Grains in Bolivia and Peru. Sustainability, 6: 1283-1312. DOI: 10.3390/su6031283

Saramma G, Padmaja C. 2013. Effects of the methanol extract of Ocimum gratissimum on cumen hydroperoxide-induced oxidative stress on rat liver tissue. Int. J. Biol. Chem. Sci., 7(1): 33-46. DOI: http://dx.doi.org/10.4314/ijbcs.v7i1i.4

Schippers RR. 2000. African Indigenous Vegetables. An Overview of the Cultivated
Species. Chatham, U.K., NRI, CTA, DFID.

Shebu T, Sewuese T. 2014. Residents' perception of environmental quality in judges quarters of Makurdi, Nigeria. $J$. Human Soc. Sci. Res., 1(1): 39 - 49.

Smith FI, Eyzaguirre P. 2007. African Leafy Vegetables: Their Role in the World Health Organization's Global Fruit and Vegetables Initiative. Afr. J. Food Agric. Nutri. Dev., 7(3): 1-17.

Zobolo AM, Mkabela QN. 2006. Traditional knowledge transfer of activities practised by woman to manage medicinal and food plant gardens. Afr. J. Ran. For. Sci., 23: 77-80. DOI: htpps://doi.org/10.2989/ 10220110609485889. 